\title{
Evaluation of the Protective Effects of Bitter Leaf (Vernonia amygdalina) on Haematological Indices of Rats Fed with Crude Oil Treated Diet
}

\author{
ACHUBA, FI \\ Department of Biochemistry, Delta State University, PMB 1, Abraka Nigeria. Email: achubabch@yahoo.com
}

\begin{abstract}
A lot of researches are ongoing on the use of plant to ameliorate the toxicity of various toxicants. This study evaluated the protective effects of bitter leaf (Vernonia amygdalina) on haematological indices of rats fed with crude oil treated diet. Twenty four male albino Wister rats with weight range of $200.75 \mathrm{~g}-217.54 \mathrm{~g}$ were used for the experiment and were randomly assigned to six groups: group A: Control; group B: Fed with $100 \mathrm{~g}$ of feed $+5.0 \mathrm{~g}$ of bitter leaf; group C: Fed with $100 \mathrm{~g}$ of feed $+10.0 \mathrm{~g}$ of bitter leaf; group D: Fed with $100 \mathrm{~g}$ of feed $+10 \mathrm{~g}$ of bitter leaf $+4.0 \mathrm{ml}$ of crude oil; group E Fed with $100 \mathrm{~g}$ of feed $+5.0 \mathrm{~g}$ of bitter leaf $+4.0 \mathrm{ml}$ of crude oil; group F: Fed with $100 \mathrm{~g}$ of feed $+4 \mathrm{ml}$ of crude oil. The results showed that treatment of diets with bitter leaf minimized crude oil toxicity, as red blood cell count, haemoglobin concentration; hematocrit values and white blood cell indices were maintained close of the control values. This study indicates that intake of bitter leaf reduced the toxic effect of crude oil treated diet on animals. Therefore, consumption of bitter leaf should be encouraged among the inhabitants of crude oil bearing communities of the world who are exposed to crude oil contaminated food and water.
\end{abstract}

DOI: https://dx.doi.org/10.4314/jasem.v22i4.8

Copyright: Copyright @ 2018 Achuba. This is an open access article distributed under the Creative Commons Attribution License (CCL), which permits unrestricted use, distribution, and reproduction in any medium, provided the original work is properly cited.

Dates: Received: 17 March 2018; Revised: 07 April: 2018; Accepted: 09 April 2018

Keywords: Bitter leaf, Crude oil, Diet, Rats

In the Niger Delta area of Nigeria some rural dwellers are exposed to crude oil because they use the chemical in various forms to treat a variety of ailments. They do this either by ingesting the crude oil or taken in combination with other substances (Dienye, 2012). In addition, humans get exposed to crude oil by consuming contaminated food, either directly or through the food chain (Sunmonu and Oloyode, 2007). Crude oil is injurious to animal's health (Achuba and Ogwumu 2014a; Achuba Nwokogba 2015a), which can be acute or chronic. Acute exposure of animals to crude oil usually result in eye irritation, nausea, vomiting, diarrhea and confusion, while chronic effects of petroleum hydrocarbon include decreased immune function, organ damage, biochemical and physiological abnormalities. (Unwin et al., 2006; Tormoehlen et al., 2014; Achuba and Nwokogba, 2015b; Achuba et al. 2016). In fact, petroleum hydrocarbon causes metabolic imbalances in experimental animals (Achuba et al., 2016). In addition, crude oil had been implicated in the alteration of haematological parameters in animal models (Ita et al., 2011; Ita et al., 2013; Achuba and Nwokogba 2015a). Moreover, researchers have shown that antioxidants such as vitamins (Achuba and Otuya, 2006), palm oil (Achuba and Ogwumu,2014b), honey (Achuba and Nwokogba,2015ab) and Moringa oleifera (Ujah et al., 2013; Achuba et al., 2016) can be used to attenuate petroleum hydrocarbon toxicity in animals.

Bitter leaf (Vernonia amygdalina) is an important medicinal plant which has hypoglycemic, anti-diabetic and anticholesterol properties (Kigigha, et al., 2015; Owen et al., 2011). Moreover, the extract has been found to mitigate chemical toxicity (Ikeh et al., 2014). However, information on the use of bitter leaf as an antidote for toxicity of crude oil tainted diets in rats is scanty. Therefore, the aim of this study was to evaluate the protective potency of Vernonia amygdalina treated diet against crude oil toxicity

\section{MATERIALS AND METHODS}

Bitter leaf was obtained from a local farm in Abraka. Identification was performed by the Department of Botany, Delta State University, Abraka, Nigeria. A local animal dealer supplied the experimental rats. Supply of crude oil was done by Nigerian National Petroleum Corporation (NNPC), Port Harcourt, Nigeria.

Experimental Design: Twenty four rats (average weight $200.75 \mathrm{~g}-217.54 \mathrm{~g}$ and age 3-4 months) and assigned into groups in different compartments, each containing four rats. They were fed with just growers mash and clean water throughout the one week of 
acclimatization. After acclimatization, each group was subjected to different mixture of feed as group A for Control; group B those fed with $100 \mathrm{~g}$ of feed $+5.0 \mathrm{~g}$ of bitter leaf, group $C$ those fed with $100 \mathrm{~g}$ of feed $+10.0 \mathrm{~g}$ of bitter leaf; group D for those fed with $100 \mathrm{~g}$ of feed $+10 \mathrm{~g}$ of bitter leaf $+4.0 \mathrm{ml}$ of crude oil; group $\mathrm{E}$ for those fed with $100 \mathrm{~g}$ of feed $+5.0 \mathrm{~g}$ of bitter leaf $+4.0 \mathrm{ml}$ of crude oil and group $\mathrm{F}$ for those fed with $100 \mathrm{~g}$ of feed $+4 \mathrm{ml}$ of crude oil.

The rats were exposed to the diets for thirty days and had free access to clean drinking water.

Determination Haemoglobin Concentration and Red Cell Indices: After thirty days blood samples were collected from each of the groups through heart puncture and used to determine heamatological indices using standard procedures. The concentration of haemoglobin and Packed Cell Volume were determined as reported by Achuba and Ogwumu (2014a). The Mean cell volume (MCV), the mean cell haemoglobin $(\mathrm{MCH})$ and the MCHC were determined according to methods reported by Achuba et al., (2016). Neuberger rule counting chamber (Haemocytometer) was used to estimate the white blood cell count (WBC).

\section{RESULTS AND DISCUSSION}

Crude oil is a potential industrial, domestic and environmental toxicant (Onwurah et al., 2013 Oguwike et al., 2014; Rostami and Soltan, 2016; Adienbo and Nwafor, 2010). This is the basis for the toxicity observed in this investigation (Table 1), which is in tandem with earlier studies (Achuba and Ahwin, 2009; Achuba and Ogwumu, 2014a; Achuba and Nwokogba, 2015). It is reported that reduction in haematological index is an indication of anemic state of an animal (Christain et al., 2016). In addition, the increase in WBC indicates response of the immune system to disease stimulating toxicants (Ita et al., 2013; Da Silva Júnior et al., 2013; Okoye et al., 2014).This explains why there is alteration in immune cells in this study (Table 1), which agrees with the report of Okonkwo et al (2016). Previous studies indicated that certain organic and inorganic substances can mitigate the toxic effect of petroleum hydrocarbon (Achuba and Nwokogba, 2015b; Achuba et al., 2016). This is consistent with the result of the present study. The addition of bitter leaf to diets pretreated with crude oil reduced the deleterious effect of hydrocarbon on the exposed animals. In fact, the wound healing property of bitter leaf is previously documented (Oguwike et al., 2014).

Table 1: Effect of bitter leaf on hematological indices of rats fed with hydrocarbon treated diet

\begin{tabular}{|c|c|c|c|c|c|c|}
\hline & A & $\mathrm{B}$ & $\mathrm{C}$ & $\mathrm{D}$ & $\mathrm{E}$ & $\mathrm{F}$ \\
\hline $\operatorname{RBC}\left(10^{3 /} \mu \mathrm{l}\right)$ & $7.93 \pm 0.97^{\mathrm{a}}$ & $8.45 \pm 0.43^{\mathrm{a}}$ & $7.32 \pm 0.49^{\mathrm{a}}$ & $7.84 \pm 0.49^{\mathrm{a}}$ & $7.69 \pm 0.18^{\mathrm{a}}$ & $7.01 \pm 0.27^{b}$ \\
\hline HGB (g/dl) & $14.68 \pm 0.39^{\mathrm{a}}$ & $14.57 \pm 0.43^{\mathrm{a}}$ & $14.35 \pm 0.61^{\mathrm{a}}$ & $13.41 \pm 0.88^{b}$ & $13.20 \pm 0.20^{\mathrm{b}}$ & $13.18 \pm 0.27^{\mathrm{b}}$ \\
\hline HCT (\%) & $44.68 \pm 0.39^{\mathrm{a}}$ & $42.43 \pm 1.45^{\mathrm{b}}$ & $42.10 \pm 0.80^{\mathrm{b}}$ & $40.73 \pm 1.16^{\mathrm{b}}$ & $39.40 \pm 0.70^{\mathrm{b}}$ & $37.25 \pm 0.50^{\mathrm{b}}$ \\
\hline WBC $\left(10^{3 / \mu 1}\right)$ & $6.35 \pm 0.48^{\mathrm{a}}$ & $4.30 \pm 0.29^{b}$ & $5.53 \pm 0.36^{\mathrm{b}}$ & $5.85 \pm 0.31^{\mathrm{a}}$ & $3.17 \pm 0.38^{b}$ & $2.23 \pm 0.22^{\mathrm{b}}$ \\
\hline MON (\%) & $1.45 \pm 0.13^{\mathrm{a}}$ & $5.55 \pm 0.21^{\mathrm{b}}$ & $0.80 \pm 0.18^{b}$ & $0.73 \pm 0.10^{\mathrm{b}}$ & $0.87 \pm 0.06^{\mathrm{b}}$ & $0.40 \pm 0.08^{\mathrm{b}}$ \\
\hline NEU (\%) & $16.05 \pm 0.93^{\mathrm{a}}$ & $12.03 \pm 0.28^{b}$ & $18.23 \pm 0.65^{\mathrm{b}}$ & $12.33 \pm 0.60^{\mathrm{b}}$ & $11.63 \pm 0.85^{b}$ & $13.28 \pm 0.62^{b}$ \\
\hline EOS (\%) & $1.15 \pm 0.13^{\mathrm{a}}$ & $1.18 \pm 0.13^{\mathrm{a}}$ & $1.63 \pm 0.21^{\mathrm{b}}$ & $3.18 \pm 0.25^{\mathrm{b}}$ & $2.77 \pm 0.15^{\mathrm{b}}$ & $2.27 \pm 0.25^{\mathrm{b}}$ \\
\hline BAS (\%) & $3.05 \pm 0.13^{\mathrm{a}}$ & $13.18 \pm 0.33^{b}$ & $3.35 \pm 0.39^{\mathrm{a}}$ & $4.65 \pm 0.56^{\mathrm{b}}$ & $6.46 \pm 0.49^{\mathrm{b}}$ & $7.90 \pm 0.22^{\mathrm{b}}$ \\
\hline $\operatorname{LYM}\left(10^{3 /} \mu \mathrm{l}\right)$ & $5.15 \pm 0.26^{\mathrm{a}}$ & $2.95 \pm 0.13^{b}$ & $4.30 \pm 0.37^{b}$ & $4.45 \pm 0.39^{b}$ & $2.33 \pm 0.25^{\mathrm{b}}$ & $1.55 \pm 0.22^{\mathrm{b}}$ \\
\hline PLT $\left(10^{3} / \mathrm{ul}\right)$ & $464.0 \pm 12.91^{\mathrm{a}}$ & $632.25 \pm 7.41^{\mathrm{b}}$ & $537.25 \pm 8.77^{b}$ & $376.0 \pm 8.60^{\mathrm{b}}$ & $228.33 \pm 4.93^{\mathrm{b}}$ & $270.75 \pm 1.71^{\mathrm{b}}$ \\
\hline $\operatorname{MCV}\left(\mu M^{3}\right)$ & $58.55 \pm 0.58^{\mathrm{a}}$ & $36.15 \pm 24.77^{\mathrm{a}}$ & $53.30 \pm 1.26^{\mathrm{a}}$ & $47.70 \pm 0.84^{\mathrm{a}}$ & $50.20 \pm 1.21^{\mathrm{a}}$ & $47.95 \pm 5.38^{\mathrm{a}}$ \\
\hline MCH (pg) & $19.03 \pm 0.26^{\mathrm{a}}$ & $17.15 \pm 0.21^{\mathrm{b}}$ & $18.13 \pm 1.03^{\mathrm{a}}$ & $15.90 \pm 1.22^{\mathrm{b}}$ & $17.07 \pm 0.15^{b}$ & $17.55 \pm 0.45^{\mathrm{b}}$ \\
\hline $\mathrm{MCHC}(\mathrm{g} / \mathrm{dl})$ & $32.53 \pm 0.51^{\mathrm{a}}$ & $33.28 \pm 0.57^{\mathrm{a}}$ & $35.95 \pm 0.97^{\mathrm{b}}$ & $33.70 \pm 0.84^{\mathrm{a}}$ & $33.50 \pm 0.79^{\mathrm{a}}$ & $34.18 \pm 1.43^{\mathrm{a}}$ \\
\hline RDW (\%) & $17.60 \pm 0.83^{\mathrm{a}}$ & $17.25 \pm 0.29^{\mathrm{a}}$ & $16.80 \pm 0.46^{\mathrm{a}}$ & $16.53 \pm 0.59^{\mathrm{a}}$ & $17.10 \pm 0.20^{\mathrm{a}}$ & $17.05 \pm 0.13^{\mathrm{a}}$ \\
\hline
\end{tabular}

An acute onset of disease process increases RDW and reduces the number of eosinophils, monocytes, basophils and lymphocytes (Förhécz et al., 2009). It is no surprise that exposure of subjects to petroleum hydrocarbon could elicit disease process (Ita et al., 2015).This agrees with the present investigation that showed alterations in white blood cell profile ( Table $1)$.

Similarly, inculcation of ground bitter leaf into the contaminated diets before feeding the rats maintained white blood cell types relative to the level in control animals. However, the white blood types were enhanced by bitter leaf in diet close to values in control rats. The immunostimulant property of bitter leaf was earlier reported (Osho et al., 2014).

This study was able to establish that intake of bitter leaf ameliorated haematotoxicity of petroleum hydrocarbon treated diet on exposed animals. Therefore, intake of bitter leaf should be encouraged among the inhabitants of crude oil bearing communities of the world.

\section{REFERENCES}

Achuba, FI; Awhin, PE. (2009). Protective influence of antioxidant vitamins on hematological indices 
of rabbits fed crude-oil-contaminated diet. Toxicol. Environ. Chem. 9(3):505 -510

Achuba, FI; Nwokogba, CC (2015a).Effect of honey supplementation on haematological parameters of wistar albino rats fed hydrocarbon contaminated diets. Biokemistri 27 (1) 44-49

Achuba, FI; Nwokogba, CC (2015b). Effects of honey supplementation on hydrocarbon-induced kidney and liver damage in wistar albino rats. Biokemistri 27 (1) 50-55

Achuba, FI; Ogwumu, MD (2014a). Effect of palm oil and beef liver on diesel-induced haematotoxicity in wistar albino rats. Biokemistri 26 (4) 120-123

Achuba, FI; Ogwumu, MD (2014b). Possible protective role of palm oil and beef liver on the kidney and liver of wistar albino rats fed dieselcontaminated diet. Biokemistri 26 (4) 124-129

Achuba, FI; Otuya, EO (2006). Protective influence of vitamins against petroleum induced free radical toxicity in rabbit. Environmentalists 26: 295-300

Achuba, FI; Ubogu, LA; Ekute, BO (2016). Moringa oleifera attenuates crude oil contaminated diet induced biochemical effects in wistar albino rats. UK J. Pharm. Biosci. 4(5) 70-77

Adienbo, OM; Nwafor, A (2010). Effect of prolong exposure to gas flaring on some haematological parameters of humans in the Niger Delta region of Nigeria. J. Appl. Sci. Environ. Manage 14(1) $13-$ 15

Christian, SG; Elekima, I; Obisike, UA; Aleru, CP (2016). Effect of petroleum on haematological parameters and lead level in fuel attendants in Port Harcourt, Nigeria. Int. J. Sci. Res. 5 (3): 280-283

Da Silva Júnior FMR; De Almeida, K.A.; Patrick, F; Silva, PF; Muccillo-Baisch, A L(2013) Hematological profile as a crude oil exposurerelated marker in wild rodents. J. Biosci. Biotechnol. 2(2): 89-94.

Dienye, PO; Akani, AB; Itimi, K (2012). Uses of crude oil as traditional medicine: a survey of mothers in a rural clinic in South-south Nigeria. Rural Remote Health 12: 1-9

Förhécz, Z; Gombos, T; Borgulya, G; Pozsonyi, Z; Prohászka, Z; Jánoskuti, L (2009). Red cell distribution width in heart failure: prediction of clinical events and relationship with markers of ineffective erythropoiesis, inflammation, renal function, and nutritional state. Am. Heart J. 158 (4):659-66.

Ikeh, CK.; Ikeh, PE; Ezike, CA (2014).Protective potential of aqueous leaf extract of Vernonia amygdalina in cyclophosphamide-induced myelotoxicity. IOSR J. Pharm. 4 (3):6-14

Ita SO; Esther OA; Dara E.A; Atim BA; Eme EO (2013). Vitamin C or E supplementation ameliorates Nigerian Bonny Light Crude Oilinduced erythrocytes haemolysis in male Wistar rats. Biochem. Mol. Biol. 1(3):44-51.

Ita, SO; Udofia, UA (2011). Comparative study of some haematological parameters in rats following ingestion of crude oil (Nigerian Bonny Light), petrol, kerosene and diesel. Asian J. Biol. Sci. 4(6):498-505

Ita, SO; Dumawara, BL; Udofia, U; Ojobo, EE (2015). Effects of Nigerian Bonny light crude oil on some immunological parameters: The role of antioxidant vitamins $\mathrm{C}$ and $\mathrm{E}$ and honey in male Wistar Rats. J. Med. Biol. Sci. Res. 1 (7): 71-77

Ita, SO; Aluko, EO; Olubobokun, TO; Okon, UA; Antai, AB; Osim, E E (2014). The Relationship between Nigerian Bonny light crude oil-induced hypoglycaemia and endogenous serum insulin concentration in male wistar rats: The role of antioxidant vitamins C and E. Am. J. Mol. Biol. (4): $81-88$

Kigigha, LT; Onyema, E (2015). Antibacterial activity of bitter leaf (Vernonia amygdalina) soup on Staphylococcus aureus and Escherichia coli). Sky J. Microbiol. Res.3 (4):041 - 045

Oguwike, FN; Offor CC; Onubeze, DPM; Nwadioha, AN (2014). Evaluation of Activities of Bitter leaf (Vernonia amygdalina) extract on Haemostatic and Biochemical Profile of Induced Male Diabetic Albino Rats. J. Dental Med. Sci. 11(2) 60-64

Okonkwo, COJ; Ehileboh, AD; Nwobodo, EC; Dike, CC( 2016) .The effects of acute gasoline vapour inhalation on some haematological indices of albino Wistar rats. J. Acute Dis. 5(2): 123-125

Okoye, JO; Ngokere, AA; Chizoba, O; Okeke, CO (2014). Biochemical, haematological and 
histological effects following Escravos crude oil ingestion by Chinchilla rabbits International. $J$. Med. Med. Sci. 6(2): 63-68

Onwurah, FB; Okejim, J; Ajie, OC (2013). Effect of crude oil pollution on tilapia live performance. Asian J. Nat. Appl. Sci. 2 (1) 23-26

Osho, IB.; Akindahunsi, A; Igbasan, FA; Adekunle, DJ (2014). Effect of orally administered bitter leaf (Vernonia amygdalina) extract on the growth performance and haematological parameters of broiler chicken. J. Vet. Med. Animal Health. 6(10):251-256

Owen, JO; Amakiri, AO; .Karibi-Botoye, TA (2011). Lipid - lowering effects of bitter leaf (Vernonia amygdalina) in broiler chickens fed finishers' mash. Agric. Biol. J. North Am. 2(6): 1038-1041

Owu, DU; Udoete, UB, Nyoh, AN; Eyong, EU (2005). Effect of bonny light crude oil on some haematological parameters of guinea pigs. Biokemistri, 17(2):165- 170
Rostami, HK; Soltani, M (2016). Effects of acute crude oil exposure on basic physiological functions of Persian sturgeon, Acipenser persicus. Caspian J. Environ. Sci. 14 (1) 43 53

Sunmonu TO; Oloyede, OB (2007). Biochemical assessment of the effects of crude oil contaminated catfish (Clarias gariepinus) on the hepatocytes and performance of rat. Afr. J. Biochem. Res. 1 (5): 083-089

Tormoehlen, LM; Tekulve, K.J; Nañagas KA. (2014) Hydrocarbon toxicity: A review. Clin. Toxicol. 52 (5): 479-489

Ujah, OF; Ujah, IR.; Johnson, JT; Oka, VO (2013). Effect of ethanolic leaf extract of Moringa oleifera on haematological and biochemical parameters of rats. J. Nat. Prod. Plant Resource, $3(2): 10-14$

Unwin J; Cocker J; Scobbie, E; Chambers, H (2006). An assessment of occupational exposure to polycyclic aromatic hydrocarbons in the UK: Supplementary Information. The Ann. Occup. Hyg. 50 (4) 395-403 